\title{
Factors Influencing American Woodcock Hunter Satisfaction in Canada
}

CHRISTIAN ROY, ${ }^{1}$ Canadian Wildlife Service - National Capital Region, Environment and Climate Change Canada, Gatineau, Quebec, Canada.

MICHEL GENDRON, Canadian Wildlife Service - National Wildlife Research Centre, Environment and Climate Change Canada, Ottawa, Ontario, Canada.

SHAWN W. MEYER, Canadian Wildlife Service - Ontario Region, Environment and Climate Change Canada, Ottawa, Ontario, Canada.

J. BRUCE POLLARD, Canadian Wildlife Service - Atlantic Region, Environment and Climate Change Canada, New Brunswick, Canada.

J. RYAN ZIMMERLING, Canadian Wildlife Service - National Capital Region, Environment and Climate Change Canada, Gatineau, Quebec, Canada.

\begin{abstract}
From 1991 to 2005, we surveyed American woodcock (Scolopax minor; hereafter, woodcock) hunters in 3 Canadian provinces to assess hunter satisfaction. Across all submitted reports, $42.0 \%$ of the respondents reported a 'poor' experience, $35.2 \%$ of the hunters reported an 'average' experience, and $22.1 \%$ of the hunters reported a 'good' experience. We analyzed hunter satisfaction rate with an ordered logistic regression that included province, Singing Ground Survey Population Index (SGS index), number of woodcock harvested, hunting effort (hours hunted), environmental conditions before and during the nesting and brood-rearing periods (i.e., prior to the hunting season), precipitation during the post-fledging period, and year as explanatory variables. We also included a random effect for each individual hunter, to account for repeated answers, and for year, to account for short-term irregular perturbations in hunter satisfaction. Hunters from Nova Scotia were on average more satisfied than hunters from Ontario. Hunter satisfaction was positively correlated with the SGS index and the number of woodcock harvested by the hunter during a hunting trip. Hunter satisfaction was negatively correlated with the amount of precipitation during the nesting period and positively correlated with the amount of precipitation during the post-fledging period. However, there was considerable variation in individual hunter response, with $27.7 \%$ of the hunters more satisfied than average and $22.8 \%$ less satisfied than average. In fact, the individual hunter response accounted for approximately $75.0 \%$ of the variability observed in the model, indicating that accounting for hunter satisfaction would require further investigation. In the meantime, promoting woodcock habitat conservation in southern Canada could increase woodcock populations, harvest opportunity, and, by extension, hunter satisfaction.
\end{abstract}

Proceedings of the American Woodcock Symposium 11: 94-102

KEY WORDS: American woodcock, hunter satisfaction, hunter success, hunter survey, human dimensions

A fundamental goal of wildlife management is to maintain sustainable game populations while, at the same time, providing hunters with quality recreational opportuni- ties (Vaske et al. 1986, Andersen et al. 2014). Whereas the North American model of conservation has provided guidance to wildlife managers in terms of how resources

1 email: christian.roy3@canada.ca 
should be allocated and managed to successfully manage wildlife resources, it has provided little guidance in terms of human-wildlife dimensions (Geist et al. 2001, Gigliotti et al. 2009). Consequently, wildlife managers have acquired substantial knowledge on game species (e.g., life history, habitat use, etc.), but their understanding of hunter motivations and behavior has lagged (Decker et al. 198o, Anderson et al. 2007, Gigliotti et al. 2009). Part of the problem is that because of the strong hunting tradition in North America, hunter numbers largely have been taken for granted in management decisions. The persistent decline in hunter numbers, in spite of good hunting opportunities in recent years for many species, has forced managers to reconsider their approach and increase their effort into assessing hunter satisfaction and identifying the factors that drive their motivation (Enck et al. 2000, Vrtiska et al. 2013).

Harvest of game can affect hunter satisfaction, which in turn is one factor that can influence future intentions to hunt (Frey et al. 2003, Brunke and Hunt 2008). In Canada, both the total harvest of American woodcock (Scolopax minor; hereafter woodcock) and the number of migratory gamebirds hunters show a long-term decline (Gendron and Smith 2017). Few studies have addressed the motivation and satisfaction of small game hunters in North America (but see: Hayslette et al. 2001, Frey et al. 2003), with most of the research focused on ungulates and waterfowl (Decker et al. 1980, Vaske et al. 1986, Hammitt et al. 1990, Schroeder et al. 2006, Brunke and Hunt 2008). Applying prior findings to woodcock hunters in Canada is complicated by the variability in hunter attitudes and preferences and by the factors found to drive hunter satisfaction (Decker et al. 1980, Hammitt et al. 1990, Frey et al. 2003). Currently, little published information exists on woodcock hunter satisfaction in Canada, but from 1991 to 2005, the Canadian Wildlife Service conducted a mail questionnaire targeting woodcock hunters to gauge their hunting habits and level of satisfaction. While the survey was restricted to hunters in Ontario, New Brunswick, and Nova Scotia, and response was voluntary, the responses gathered provide some insight into the motivation of woodcock hunters in Canada.

Our objectives in this paper were to quantify the satisfaction of woodcock hunters in Canada who answered the questionnaire, and to assess variation in their responses over space and time. Based on previous hunter-satisfaction studies, we included year, province, and specific questionnaire data, namely the number of woodcock harvested and hours hunted as declared by the hunter (Guttery et al 2016, Andersen et al. 2014, Schulz et al. 2010, Brunke and Hunt 2008, Frey et al. 2003). We included the Singing Ground Survey population index (SGS; Seamans and Rau 2016) as a proxy for the abundance of adults in the fall, and environmental variables in the spring and summer as proxies for number of juveniles in the fall (i.e. productivity; Roy et al., in press, Schulz et al. 2010). We did not consider changes in hunting regulations in our analysis because the daily bag limit (8 woodcocks per day) remained constant throughout the study period.

\section{Methods \\ HUNTER SATISFACTION}

Between 1991 and 2005, data from the Canadian National Harvest Survey (Gendron and Smith 2017) was used to identify woodcock hunters. Each year, wing envelopes were mailed to approximately 450 woodcock hunters. Hunters were randomly selected based on whether they
Table 1: Explanatory variables included in the ordered logistic regression model to explain the satisfaction level of woodcock hunters in Canada surveyed between 1991 and 2005 by province where the hunting trip occurred.

\begin{tabular}{lll}
\hline Variable & $\begin{array}{l}\text { Expected effect } \\
\text { on Woodcock } \\
\text { Population }\end{array}$ & $\begin{array}{l}\text { Expected effect on } \\
\text { Hunter Satisfaction }\end{array}$ \\
\hline $\begin{array}{l}\text { Province } \\
\text { Year }\end{array}$ & $\begin{array}{l}\text { None } \\
\text { None }\end{array}$ \\
$\begin{array}{l}\text { Singing Ground } \\
\text { Survey (SGS) } \\
\text { Population Index }\end{array}$ & $\begin{array}{l}\text { High SGS index } \\
\text { indicates a high } \\
\text { breeding population }\end{array}$ & $\begin{array}{l}\text { High SGS population } \\
\text { index increases } \\
\text { satisfaction }\end{array}$ \\
$\begin{array}{l}\text { Declared harvest } \\
\text { Declared effort }\end{array}$ & $\begin{array}{l}\text { Harvest increases } \\
\text { satisfaction }\end{array}$ \\
$\begin{array}{l}\text { Spring snow cover } \\
\text { Late snow cover } \\
\text { decreases female } \\
\text { productivity }\end{array}$ & $\begin{array}{l}\text { Late snow cover } \\
\text { decreases satisfaction }\end{array}$ \\
$\begin{array}{l}\text { Precipitation } \\
\text { before the } \\
\text { nesting period }\end{array}$ & $\begin{array}{l}\text { High precipitation } \\
\text { decreases female } \\
\text { productivity }\end{array}$ & $\begin{array}{l}\text { High precipitation } \\
\text { decreases satisfaction }\end{array}$ \\
$\begin{array}{l}\text { Precipitation } \\
\text { during the } \\
\text { nesting and brood } \\
\text { rearing periods }\end{array}$ & $\begin{array}{l}\text { High precipitation } \\
\text { decreases female } \\
\text { productivity and } \\
\text { juvenile survival rate }\end{array}$ & $\begin{array}{l}\text { High precipitation } \\
\text { decreases satisfaction }\end{array}$ \\
$\begin{array}{l}\text { Precipitation } \\
\text { during the post- } \\
\text { fledging period }\end{array}$ & $\begin{array}{l}\text { High precipitation } \\
\text { increases juvenile } \\
\text { and adult } \\
\text { survival rates }\end{array}$ & $\begin{array}{l}\text { High precipitation } \\
\text { increases satisfaction }\end{array}$ \\
\hline
\end{tabular}


had participated in the Canadian National Harvest Survey during the previous year and demonstrated an interest in woodcock hunting. The National Harvest Survey does not address the number of woodcock hunters directly, so hunters had to declare an interest in hunting non-waterfowl game species (e.g., woodcock, rails, coots, etc.) and successfully harvested $\geq 1$ woodcock in the previous year to be considered. The survey was limited to hunters residing in Ontario, New Brunswick, and Nova Scotia. The hunters selected were asked to send in 1 wing from each woodcock they harvested and to provide details about each of their hunting trips on a report card. Hunters were asked to report the number of woodcock they flushed, the numbers of hours they hunted, and the number of woodcock they harvested personally, and to rate their hunting experience as 'poor,' 'average,' or 'good.' Hunters were asked to file a report card for each of their hunting trips, and could request additional report cards throughout the hunting season. To increase sample size, report cards were sent to hunters who had participated in the survey the previous year in addition to the $\sim 450$ hunters surveyed each year. Hunters were dropped from the survey if they did not submit a report card during an entire year, or if they requested to be removed from the survey.

\section{ENVIRONMENTAL VARIABLES}

We downloaded the Snow Cover Extent from the National Oceanic and Atmospheric Administration (NOAA) National Center for Environmental Information website (ncei.noaa.gov/data/snow-cover-extent/access/). The database consists of weekly gridded data $\left(1.0^{\circ} \times 1.0^{\circ}\right.$ grid cells $)$ documenting the occurrence of snow on the ground for the northern hemisphere, and is based on Robinson et al. (2012) methodology. For each year, we calculated the average week at which snow cover permanently disappeared in each province (i.e., averaged over each of the $1.0^{\circ} \times 1.0^{\circ}$ grid cells within each province). For Ontario, we restricted the extraction of the snow cover values below $51.75^{\circ} \mathrm{N}$ to avoid including areas that are not part of the woodcock breeding range (McAuley et al. 2013). Within each province, we centered the average week at which the snow cover permanently disappeared after extraction to capture years of "early" and "late" snowmelt.

We used the NOAA Precipitation Reconstruction over Land dataset to represent the amount of precipitation that occurred during each year. The dataset consists of monthly precipitation between 1850 and 2014 on a $1.0^{\circ} \times 1.0^{\circ}$ grid. The dataset was constructed according to methodology in Chen et al. (2002). We calculated the total amount of precipitation in each province (i.e., summed over each of the $1.0^{\circ} \times 1.0^{\circ}$ grid cells) before the start of the nesting period (April), during the nesting and brood-rearing periods (May and June), and during the post-fledging period (July). Similar to the snow cover index, we restricted the extraction of the data below $51.75^{\circ} \mathrm{N}$ in Ontario and centered the data during the survey period to identify "dry" and "wet" years within the periods of interest. We did not expect a linear relationship between precipitation and satisfaction, but rather expected the effect of precipitation to level off with increasing amount of precipitation. We therefore log transformed the precipitation data prior to centering them.

\section{Data Analysis}

We analyzed the hunter satisfaction rating (i.e., 'poor', 'average', or 'good') with an ordered logistic regression that was parametrized via the mean $(\eta)$ and cut points $(\kappa)$. The cut points define the limits between different categories on the logistic scale, and values of the observed variable (i.e., hunter satisfaction) therefore depend on whether the predicted mean has crossed a particular threshold:

$$
\begin{aligned}
& \text { satisfaction }_{\mathrm{i}}= \begin{cases}1-\operatorname{logit}\left(\eta_{i}-\kappa_{1}\right) & \text { if satisfaction } \\
\mathrm{i}=\text { Good } \\
\operatorname{logit}\left(\eta_{i}-\kappa_{1}\right)-\operatorname{logit}\left(\eta_{i}-\kappa_{2}\right) & \text { if satisfaction } \\
\mathrm{l}=\text { Average } \\
\operatorname{logit}\left(\eta_{i}-\kappa_{2}\right) & \text { if satisfaction } \\
\mathrm{i} & =\text { Poor }\end{cases} \\
& \eta_{i}=\mu_{i}+\varepsilon_{\text {hunter }_{i}}+\varepsilon_{\text {year }_{i}}
\end{aligned}
$$

where $\eta_{i}$ is the predicted mean of the observation $i$ on the logistic scale, $\mu_{i}$ is the predicted effect of the explanatory variables, $\varepsilon_{\text {hunter }}$ is a hunter-specific random effect to account for the fact that some hunters returned $>1$ report cards, and $\varepsilon_{\text {year }}$ is random effect to account for short-term irregular perturbations in hunter satisfaction. Both random effects were drawn from a normal distribution with a mean $o$ and a shared variance parameter (i.e., either $\sigma_{\text {hunter }}^{2}$ or $\sigma_{\text {year }}^{2}$ ). The predicted effect of the explanatory variables is defined as:

$$
\mu=\mathrm{X} \beta
$$

eq. 3

where $\mathbf{X}$ is a matrix holding the explanatory variables (Table 1 ) and $\beta$ is a vector holding the parameter to be estimated. We included, Year, Province, number of woodcock harvested by the hunter (declared on the report card), number of hours hunted (declared on the report card), annual provincial SGS population index, the week at which the snow cover disappeared in the province, and total precipitation before and during the nesting, brood-rearing, and post-fledging periods within the province as explanatory variables. We used Ontario as the reference class in the model. For the Year effect, we included both a linear term and random effect to distinguish the prevailing trend from the short-term irregular perturbations. We did not include the number of woodcock that the hunter declared to have flushed during each hunt in the analysis because this variable was highly correlated with the number of woodcock harvested $(r=0.8)$. 
We did not expect a temporal trend in hunter satisfaction or regional differences among hunters in the 3 provinces a priori for woodcock hunters, but included those variables because previous analysis demonstrated that there has been some temporal and spatial variation of success for woodcock hunter in Canada (Roy et al., in press). We expected both the number of woodcock harvested and the SGS index to have a positive influence on hunting satisfaction (Schulz et al. 2010). Given that spring and early summer weather conditions affect woodcock productivity and juvenile survival rates (Rabe et al. 1983, Sepik et al. 1983, Daly et al. 2015) and are correlated to woodcock harvest in the fall (Roy et al. in press), we included explanatory variables related to spring and early summer conditions. Specifically, we included the week at which the snow cover disappeared within the province and the total precipitation before the nesting period (April), during the nesting and brood-rearing periods (May-June), and during the post-fledging period (July). We expected high amounts of precipitation before the nesting period and during the nesting and brood-rearing periods to have a negative effect on woodcock productivity (Rabe et al. 1983, Daly et al. 2015), to decrease harvest (Roy et al. in press), and therefore to affect hunter satisfaction negatively.

We also expected dry conditions during the post-fledging period to have a negative effect on juvenile survival rate (Sepik et al. 1983), to decrease harvest (Roy et al. in press), and therefore to affect hunter satisfaction negatively. We fitted the model using Stan version 2.14.1 called via the RStan package in R ( $\mathrm{R}$ Core Team 2016, Stan Development Team 2016). Stan implements Bayesian inference using a variant of the Hamiltonian Monte Carlo algorithm (Carpenter et al. 2016). Each variable was centered prior to analysis. We used non-informative priors for all parameters of the model (Appendix 1). We ran 4 chains, each of 500 iterations for the adaptation phase (discarded), followed by a further 1,000 iterations for inference. We checked for convergence by visual inspection, and by using the Gelman-Rubin diagnostic test (Gelman et al. 2013). We assessed the effects of explanatory variables using Bayesian credible intervals, where we were certain of real effects if the $95 \%$ credible intervals did not include zero. We also considered variables for which there was some evidence of effects, but more uncertainty, by determining if $90 \%$ credible intervals contained zero.

We derived variance partition coefficients (VPC) from the posterior distribution to assess the proportion of the variance that was associated with the model $\left(\sigma^{2}\right)$, the explanatory variable $\left(\sigma_{\beta}^{2}=\beta \operatorname{cov}(\mathbf{X}) \boldsymbol{\beta}\right)$, individual hunters $\left(\sigma_{\text {hunter }}^{2}\right)$, and individual years $\left(\sigma_{\text {year }}^{2}\right.$; Long 1997, Browne et al. 2005). The model variance is fixed in the parametrization of the model we used to ensure cut points can be identified, so we used the value of $\pi^{2} / 3$ for the calculation
(Browne et al 2005, Gelman and Hill 2007). For example, the VPC for hunter is defined as:

$$
\mathrm{VPC}_{\text {hunter }}=\frac{\sigma_{\text {hunter }}^{2}}{\left(\sigma^{2}+\sigma_{\beta}^{2}+\sigma_{\text {hunter }}^{2}+\sigma_{\text {year }}^{2}\right)}
$$

\section{Results}

We received 1,555 report cards from 207 hunters $(\sim 3.3 \%$ response rate) during the survey but $31.9 \%(\mathrm{~N}=496)$ of those report cards were incomplete, with either the satisfaction rating or information about the hunting trip missing, and were discarded from the analysis. Due to a clerical error, no report cards from 1996 were included in the database. In total, 166 hunters filled $\geq 1$ report card with $60.8 \%(\mathrm{~N}=101)$ from Ontario, $22.3 \%(\mathrm{~N}=37)$ from New Brunswick, and $16.9 \%(\mathrm{~N}=28)$ from Nova Scotia. On average, a hunter submitted 6 report cards, but this number was highly variable $(S D=7.9)$, with 1 hunter submitting 66 report cards. Yearly return rate ranged from 26 (1991) to 160 (1993) and averaged 81 returned cards per year $(\mathrm{SD}=41.7)$. Hunters harvested $\geq 1$ woodcock during $65.3 \%$ $(\mathrm{N}=691)$ of the hunting trips they reported. On average, hunters harvested $2(S D=2)$ woodcock per hunting trip.

Overall, $42.0 \%$ of all report cards (responses) indicated a 'poor' experience during the hunting trip, 35.2\% reported an 'average' experience, and $22.1 \%$ reported the experience as 'good. Compared to hunters from Ontario, hunters from Nova Scotia were more satisfied $(\beta=3.03$; $95 \%$ BCI $=0.65-5.45$; Fig. 1 ) and there was some tendency for the hunters from New Brunswick to be more satisfied than those from Ontario $(\beta=1.45 ; 95 \%$ BCI $=-0.77-3.57$; Fig. 1). There was a tendency for a weak, long-term decline in hunter satisfaction during the survey period $(\beta=-0.31$; $95 \% \mathrm{BCI}=-0.64-0.03)$. Hunter satisfaction was positively correlated with the SGS population index $(\beta=2.13$; $95 \%$ $\mathrm{BCI}=1.05-3.12$; Fig. 2$)$ and the number of woodcock harvested by the hunter $(\beta=0.22 ; 95 \% \mathrm{BCI}=0.09-0.35$; Fig. $2)$. The amount of precipitation during the nesting and brood-rearing periods $(\beta=-3.16 ; 95 \% \mathrm{BCI}=-5.06--1.23$; Fig. 3) was negatively correlated with hunter satisfaction, whereas the amount of precipitation during the post-fledging period $(\beta=2.25 ; 95 \% \mathrm{BCI}=0.67-3.83$; Fig. 3 ) was positively correlated with hunter satisfaction. There was also a weak negative correlation between hunter satisfaction and spring snow cover $(\beta=-0.55 ; 95 \% \mathrm{BCI}=-1.22$ - 0.09). Hunter effort $(\beta=0.06 ; 95 \%$ BCI $=-0.13-0.25)$ and the amount of precipitation before the nesting period $(\beta=-0.73 ; 95 \%$ BCI $=-2.58-0.97)$ did not substantively influence hunter satisfaction.

There was considerable variation in individual hunter satisfaction, with $27.7 \%(\mathrm{~N}=46)$ of the hunters more satisfied than the average and $22.8 \%(\mathrm{~N}=38)$ less satisfied than the average (Fig. 4). The variance partition coefficient esti- 
mates indicated that variability among hunters accounted for $76.0 \%(95 \% \mathrm{BCI}=63.6-84.9 \%)$ of the variability accounted for in the model, whereas the explanatory variables, short-term variability due to years, and residual error accounted for $10.4 \%(95 \% \mathrm{BCI}=5.1-18.1 \%), 8.2 \%$ $(95 \% \mathrm{BCI}=3.0-18.1 \%)$, and $5.4 \%(95 \% \mathrm{BCI}=3.7-7.6)$ of the variability, respectively. Although the individual hunter effect was large, it did not buffer completely against the effect of the other explanatory variables. In other words, based on model predictions, it was possible to have a small proportion of the most dissatisfied hunters report their experience as 'good', albeit only under the best circumstances (e.g., high SGS population index, full daily bag limit, and excellent conditions during the spring). In cases where hunters returned more report cards than average, the credible interval associated with the individual effect was smaller but there was no obvious correlation between the numbers of report cards submitted and satisfaction.

\section{Discussion}

Overall, most survey participants reported low satisfaction during their hunting trip. Hunter satisfaction was positively associated with hunter success, the size of the

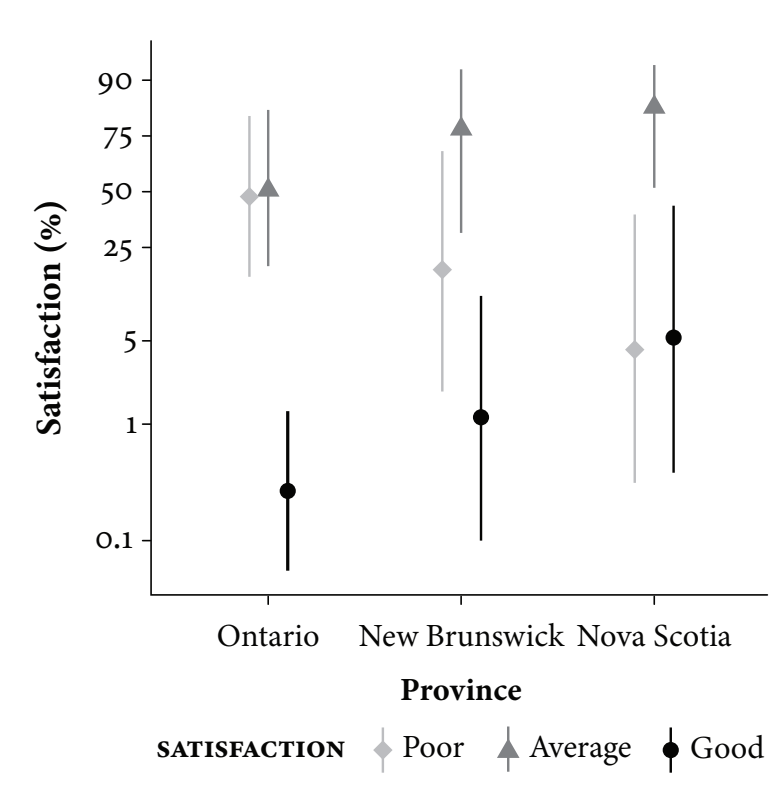

Figure 1: Predicted satisfaction of woodcock hunters in Canada, surveyed between 1991 and 2005, about their hunting trip. Hunter satisfaction was selfreported as either Poor, Average or Good in the survey. The results are presented according to the province where the hunting trip occurred. The dots represent the averages and the bars represent the $95 \%$ credible intervals. Note that the y-axis is on the logistic scale for ease of presentation. breeding population, and environmental factors during spring and early summer. However, the most important output of our model was the wide variability observed in the response among hunters.

The number of woodcock harvested had a positive effect on hunter satisfaction in our study, but only to a limited extent. Based on predictions from our model, even with a full daily bag limit of 8 woodcock, only about $1.5 \%$ of hunters would report their satisfaction as 'good' during an average year (i.e., when we isolate the effect harvest and controlled for all other variables). This finding might seem surprising, but it has been noted before that consumptive users, such as hunters, are less likely to describe their experience as 'perfect' unless they encounter exceptional circumstances (Vaske et al. 1982, 1986) and that other factors can supersede harvest success as a motivation for hunting (see discussion below). From a management perspective, our results indicate that increasing the daily bag limit would have a positive effect on hunter satisfaction, but that that effect would only be marginal at best, and that other factors might more substantively increase hunter satisfaction.

The SGS population index in the spring also had a positive effect on hunter satisfaction. Schulz et al. (2010) suggested that a high abundance of woodcock in the spring should carry over to the fall, give hunters an increased amount of harvest opportunities, and therefore increase hunter satisfaction. The state of the spring population is also likely to be noticed by hunters, which could make them prone to believe that it is either a 'good' or 'bad' year for hunting, which in turn would affect their satisfaction. Our model predicted only $6.0 \%$ of hunters would report their satisfaction as 'good' at peak abundance in the SGS population index (i.e., when we isolate the effect of the SGS population index and controlled for all other variables), which is only a modest increase. Nevertheless, comparing the predictions of the individual hunter declared harvest and the SGS population index on hunter satisfaction indicates that the effect of the SGS population index was more important than the effect of harvest itself. A similar pattern has been reported for other small game species in areas where target species abundance was low (Hayslette et al. 2001, Frey et al. 2003). However, the SGS population index in our analysis provided a province-level index for hunting opportunity rather than an index at a local hunting-trip scale, and may not be a reliable indicator of hunter experience during their hunting-trip.

The continued decline of the SGS population index in Canada suggests woodcock hunter satisfaction will continue to decline. The reasons for the decline in the woodcock breeding population in Canada remain obscure, and further work would be required to identify if breeding-ground factors are the cause of the decline (Roy et al., in press). Recent analyses suggested that the distribution of the SGS is biased towards southern Canada and 
that this coverage bias may result in inaccurate population estimates by not surveying substantial populations in northern Ontario and Quebec (Sullins et al. 2016). The observed decline in the south could thus be caused in part by a redistribution of the woodcock population during the breeding period (Roy et al. in press, Sullins et al. 2016). However, given the relationship we found between the SGS population index and hunter satisfaction, it seems that hunters are attuned to how woodcock populations are faring in southern Canada, where most Canadian hunters live. If that is the case, the state of northern breeding populations might not be of relevance to Canadian wildlife managers to maintain hunter satisfaction and, therefore, human dimension efforts should be concentrated in southern Canada where hunter density is the highest.
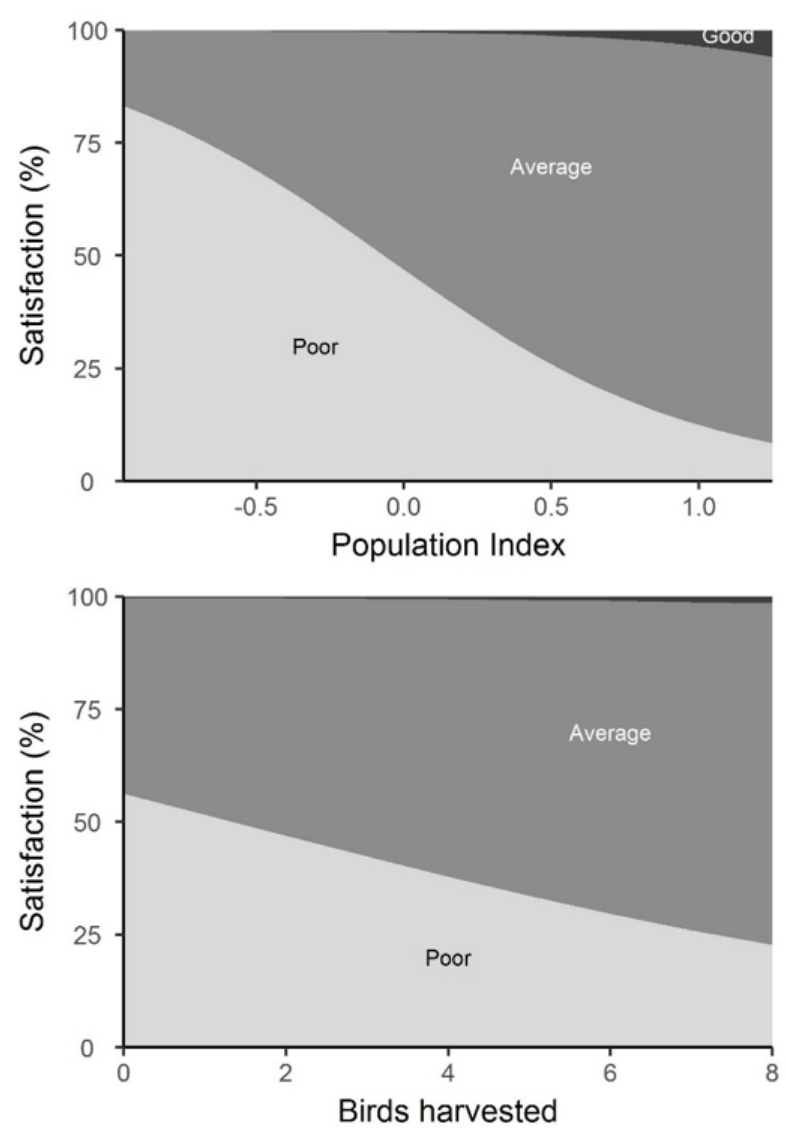

Figure 2: Mean predicted satisfaction of woodcock hunters in Ontario, Canada about their hunting trip as a function of the American Woodcock Singing Ground Survey Population Index in the spring (top), and the number of woodcocks harvested by the hunter (bottom). Hunters were surveyed between 1991 and 2005. Hunter satisfaction was self-reported as either Poor (light grey), Average (dark grey) or Good (black) in the survey.
Our results indicating an effect of precipitation during the spring and summer on hunter satisfaction support the contention that perceived hunter trip quality is tied in part to the quality of the nesting period for woodcock (Schulz et al. 2010). It has already been demonstrated that precipitation can limit the survival of juveniles during the brood-rearing period, that summer drought can increase mortality for both adults and juveniles (Rabe et al. 1983, Sepik et al. 1983, Daly et al. 2015), and that woodock harvest in Canada is correlated with spring conditions (Roy et al., in press). The number of woodcock flushes declared
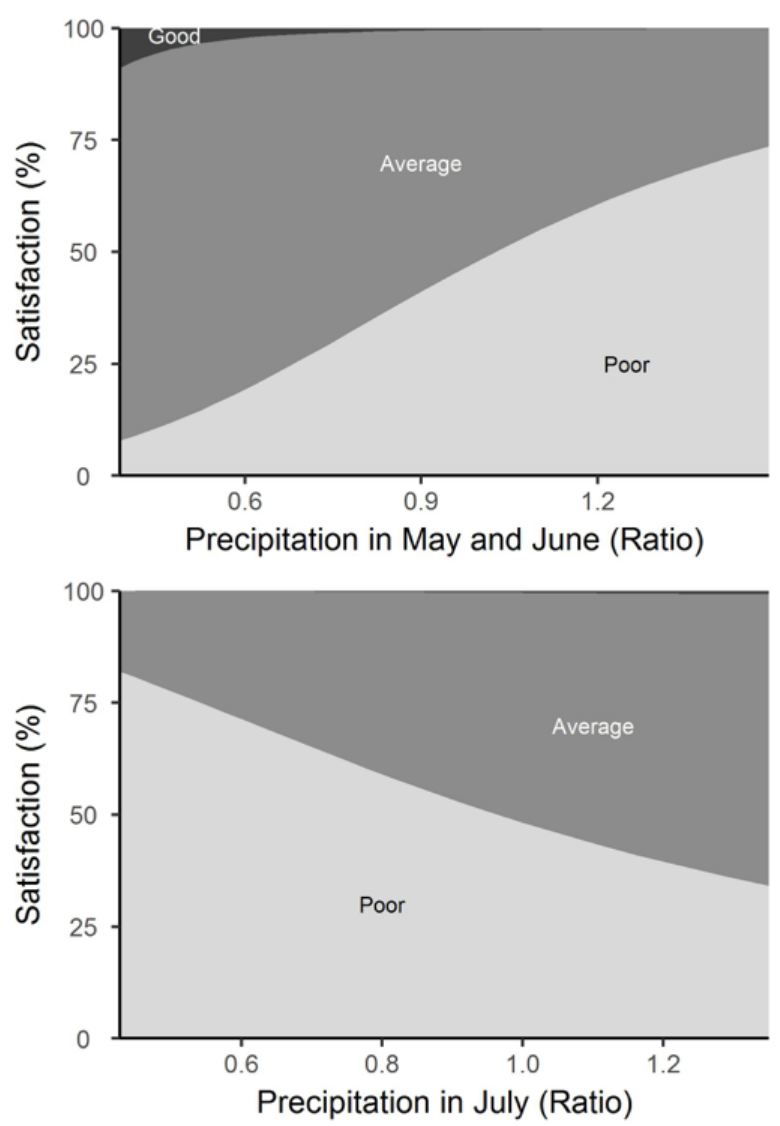

Figure 3: Mean predicted satisfaction of woodcock hunters in Ontario, Canada, about their hunting trip as a function of the amount of precipitation during the nesting and brood rearing periods (top) and the post-fledging period (bottom). Hunters were surveyed between 1991 and 2005. Hunter satisfaction was self-reported as either Poor (light grey), Average (dark grey) or Good (black) in the survey. The x-axis represents the ratio of precipitation compared to the average level of precipitation during the survey period (i.e., $0.5=$ half the average precipitation, 1 $=$ average precipitation, $2=$ double the average precipitation). 
by hunters during their hunting trips were also weakly correlated with the environmental conditions in the spring and the summer (C. Roy unpublished data). The likely explanation for our findings is that abundant precipitation during the nesting period results in a decline in nesting success and survival rates of juveniles during the brood-rearing period whereas dry conditions during the post-fledging period decrease fledgling survival by nega-

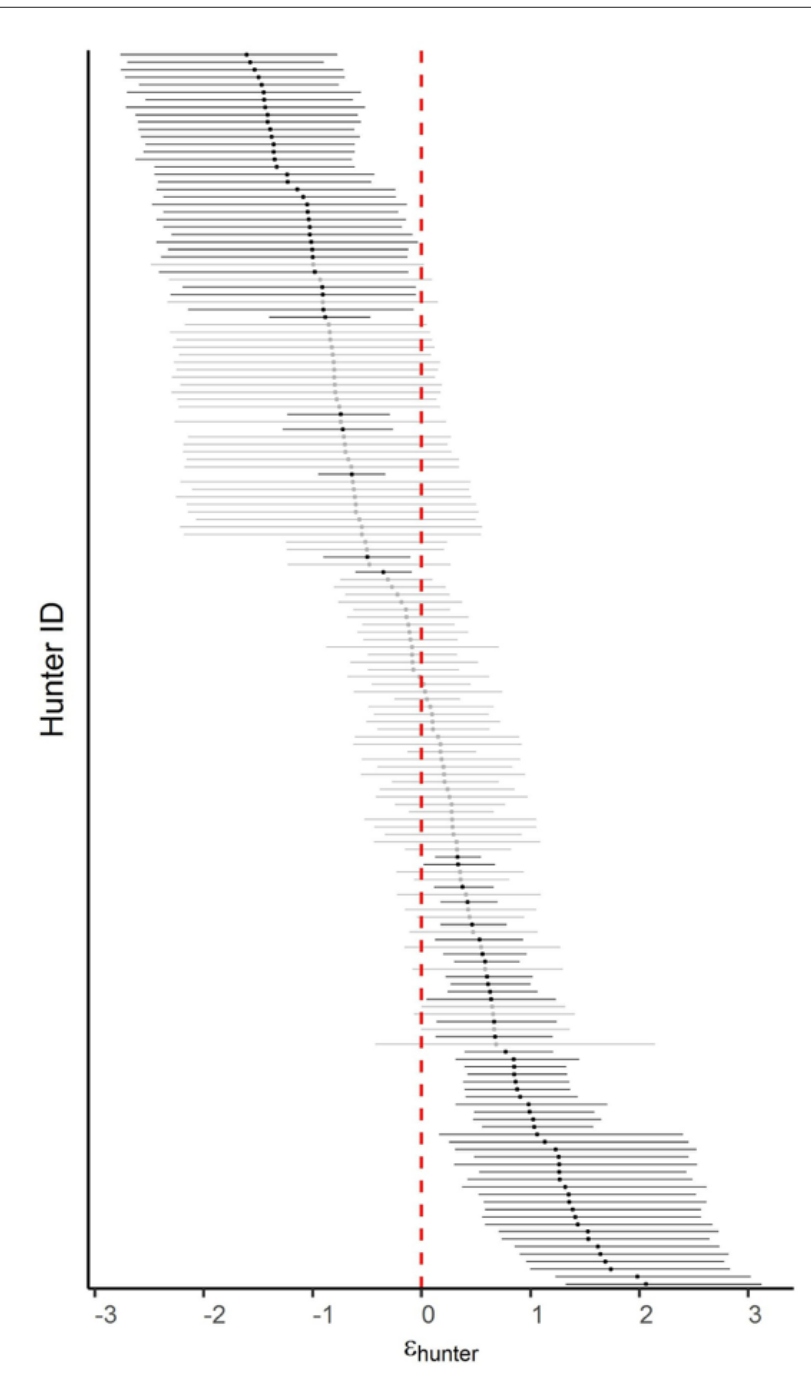

Figure 4: Individual hunter effect $\left(\varepsilon_{\text {hunter }}\right)$ in a model that predicts the satisfaction of woodcock hunters in Canada surveyed between 1991 and 2005. Negative number indicates that the hunter is less satisfied than average whereas a positive number indicates than the hunter is more satisfied than the average. Dots represent the mean and bars represent the 95\% Bayesian credible intervals. Black is used when the 95\% credible intervals of the estimates do not include zero. Individual hunter labels for each hunter on the $\mathrm{y}$-axis have been removed for clarity and anonymity. tively impacting their ability to feed (Roy et al., in press). Both of these scenarios would decrease the abundance of juveniles, which are usually more vulnerable to harvest than adults and represent a greater proportion of the harvest in the fall (Reynolds 1987, Zimmerman et al. 2010), and would thus negatively impact fall flush rates and hunting success and hunter satisfaction. Although the full mechanism that ties spring conditions to hunter satisfaction in the fall remains to be formally tested, we argue that our findings reinforce the notion that the overall conditions of the population can influence hunter satisfaction.

Overall, the variables we included in our analysis tended to have a limited effect on woodcock hunter satisfaction compared to the high variability observed among the sample of hunters that we surveyed. The variability among hunters accounted for $76.0 \%$ of the predicted variation in hunter satisfaction, whereas our explanatory variables explained only $10.5 \%$. There was a strong dichotomy between hunter satisfaction in our survey, with nearly one quarter of the hunters being either substantively more or less satisfied than average. Because we controlled for hunter success and large-scale drivers of hunting opportunity, our results indicate that there are still some important drivers of hunting satisfaction that were missing from our analysis. These results reinforce the notion that there are many other determinants affecting hunter satisfaction than hunter success or the size of game populations (Decker et al. 1980, Hammitt et al. 1990, Frey et al. 2003). Apart from successfully seeing and harvesting game, experiencing nature (Hammitt et al. 1989, Wynveen et al. 2005, Schroeder et al. 2006) and spending time with friends and family (Decker and Connelly 1989, Guttery et al. 2016) have also been cited as important drivers of satisfaction. Without formally assessing the factors that drive woodcock hunter satisfaction it will be difficult to formulate a proper hunter retention strategy. Given the variation we observed among provinces and hunters, a more thorough survey of woodcock hunters in Canada would give us a better understanding of their motivation and the factors that drive their satisfaction. Such a survey should also undertake a broader approach that seeks to identify the multiple factors (i.e., being outdoors, being with friends, connecting with nature, etc.) that lead a hunter to characterize a hunting trip as 'successful' and would help classify the hunters as a function of their attitudes and preferences. This approach is particularly enticing because it could allow managers to seek alternative paths, such as mentorship programs or access to crown lands, rather than simply targeting hunting success to retain and recruit woodcock hunters (Vaske et al. 1986).

The implications of our survey are limited in part by the methodology used to select the hunters for the survey. The hunters selected for this survey were randomly selected from the pool of hunters who had participated 
in the Canadian National Harvest Survey during the previous year and had successfully harvested $\geq_{1}$ woodcock. Consequently, our results are only applicable to hunters who had been successful in the previous year. Another major limitation of our survey was that it depended on the hunter's willingness to submit a report card. However, no data were compiled on the number of hunters that refused to answer the survey, or why a hunter stopped responding, which also limits our ability to draw broad inferences from our results. For example, the strong dichotomy we observed in hunter individual responses could be an artifact of the voluntary response of hunters to participate in the survey. Hunters that had a strong feeling about the state of the woodcock population could be more likely to return report cards than those that were indifferent.

\section{Management Implications}

Although it would be theoretically possible to maintain or increase hunter satisfaction by trying to increase the woodcock population or daily bag limits, our results suggest that such gain would be minimal, and based on the current trend of the SGS population index, which is still low on the woodcock breeding ground in Canada (Seamans and Rau 2016), such strategies do not seem likely. Increasing the breeding population in the spring could help increase hunter satisfaction, but it would require identifying the cause of the decline in the SGS population index on breeding grounds in Canada, a task that has not been done yet (Roy et al., in press). Given that habitat manipulation to improve woodcock breeding habitat might be difficult to achieve, some resources could be dedicated to understanding the high variability in hunter satisfaction that we observed in our study. Identifying the factors that drive hunter motivation could help managers design strategies to improve the hunting experience of woodcock hunters in Canada and, by extension, improve hunter retention and recruitment.

\section{Acknowledgments}

The authors thank M.C. Bateman, R.J. Hicks, and R.K. McAloney for running the wing collection and woodcock hunter satisfaction survey programs and the hunters who participated in the survey. V.I Aponte, B.S. Stevens, D.E. Andersen, and one anonymous reviewer provided helpful feedback on a previous version of the manuscript.

\section{Literature Cited}

Andersen, O., B.P. Kaltenborn, J. Vittersø, and T. Willebrand. 2014. Preferred harvest principles and regulations amongst willow ptarmigan hunters in Norway. Wildlife Biology 20:285-290.

Anderson, M.G., D. Caswell, J.M. Eadie, J.T. Herbert, M. Huang, D.D. Humburg, F.A. John-son, M.D. Koneff, S.E. Mott, T.D. Nudds, E.T. Reed, J.K. Ringelman, M.C. Runge, and B.C. Wilson. 2007. Report from the Joint Task Group for clarifying North American waterfowl management plan population objectives and their use in harvest management. U.S. Fish and Wildlife Service, Arlington, Virginia. USA.

Browne, W.J., S.V. Subramanian, K. Jones, and H. Goldstein. 2005. Variance partitioning in multilevel logistic models that exhibit overdispersion. Journal of the Royal Statistical Society: Series A (Statistics in Society) 168:599-613.

Brunke, K.D., and K.M. Hunt. 2008. Mississippi waterfowl hunter expectations, satisfaction, and intentions to hunt in the future. Human Dimensions of Wildlife 13:317-328.

Carpenter, B., A. Gelman, M. Hoffman, D. Lee, B. Goodrich, M. Betancourt, M.A. Brubaker, J. Guo, P. Li, and A. Riddell. 2016. Stan: a probabilistic programming language. Journal of Statistical Software 20:1-37.

Chen, M., P. Xie, J.E. Janowiak, and P.A. Arkin. 2002. Global land precipitation: a 50-yr monthly analysis based on gauge observations. Journal of Hydrometeorology 3:249-266.

Daly, K.O., D.E. Andersen, W.L. Brininger, and T.R. Cooper. 2015. Radio-transmitters have no impact on survival of pre-fledged American woodcocks. Journal of Field Ornithology 86:345-351.

Decker, D.J., T.L. Brown, and R.J. Gutiérrez. 1980. Further insights into the multiple-satisfactions approach for hunter management. Wildlife Society Bulletin 8:323-331.

Decker, D.J., and N.A. Connelly. 1989. Motivations for deer hunting: implications for antlerless deer harvest as a management tool. Wildlife Society Bulletin 17:455-463.

Enck, J.W., D.J. Decker, and T.L. Brown. 200o. Status of hunter recruitment and retention in the United States. Wildlife Society Bulletin 28:817-824.

Frey, S., M. Conover, J. Borgo, and T. Messmer. 2003. Factors influencing pheasant hunter harvest and satisfaction. Human Dimensions of Wildlife 8:277-286.

Geist, V., S. Mahoney, and J. Organ. 2001. Why hunting has defined the North American model of wildlife conservation. Transactions of the North American Wildlife and Natural Resources Conference 66:175-185.

Gelman, A., and J. Hill. 2007. Data analysis using regression and multilevel/hierarchical models. Cambrige Univeristy Press, Cambridge, U.K.

Gelman, A., J.B. Carlin, H.S. Stern, D.B. Dunson, A. Vehtari, and D.B. Rubin. 2013. Bayesian data analysis. Third edition edition. CRC/ Chapman \& Hall, London, U.K.

Gendron, M.H., and A.C. Smith. 2017. National Harvest Survey web site. https://wildlife-species.canada.ca/harvest-survey. 28 January 2019.

Gigliotti, L.M., D.L. Shroufe, and S. Gurtin. 2009. The changing culture of wildlife management. Pages 75-89 in J.M.J. Manfredo, D. Vaske, D.J. Decker, and E.A. Duke, editors. Wildlife and Society: The Science of Human Dimensions. Island Press, Washington, Covelo, London.

Guttery, M.R., T.A. Messmer, M.W. Brunson, J.D. Robinson, and D.K. Dahlgren. 2016. Declining populations of greater sagegrouse: hunter motivations when numbers are low. Animal Conservation 19:26-34.

Hammitt, W.E., C.D. McDonald, and F.P. Noe. 1989. Wildlife management: managing the hunt versus the hunting experience. Environmental Management 13:503-507.

Hammitt, W.E., C.D. McDonald, and M.E. Patterson. 1990. Determinants of multiple satisfaction for deer hunting. Wildlife Society Bulletin 18:331-337.

Hayslette, S.E., J.B. Armstrong, and R.E. Mirarchi. 2001. Mourning dove hunting in Alabama: motivations, satisfactions, and sociocultural influences. Human Dimensions of Wildlife 6:81-95.

Long, S.J. 1997. Regression models for categorical and limited dependent variables. SAGE Publication, London, U.K.

McAuley, D., D. Keppie, and R. Whiting Jr. 2013. American woodcock (Scolopax minor). in P.G. Rodewald, editor. The Birds 
of North America. Cornell Lab of Ornithology, Ithaca, New York, USA.

R Core Team. 2016. R: A language and environment for statistical computing. R Foundation for Statistical Computing, Vienna, Austria.

Rabe, D.L., H.H. Prince, and E.D. Goodman. 1983. The effect of weather on bioenergetics of breeding American woodcock. Journal of Wildlife Management 47:762-771.

Reynolds, R.E. 1987. Breeding duck population, production and habitat surveys, 1979-85. Transactions of the North American Wildlife and Natural Resources Conference 52:186-205.

Robinson, D.A., T.W. Estilow, and N.C. Program. 2012. NOAA Climate Date Record (CDR) of Northern Hemisphere (NH) Snow Cover Extent (SCE), Version 1. NOAA National Centers for Environmental Information. DOI: $10.7289 / \mathrm{V}_{5} \mathrm{No}_{14} \mathrm{G} 9$.

Roy, C., M. Gendron, S.W. Meyer, J.B. Pollard, J. Rodrigue and J.R. Zimmerling. 2019. Retrospective analysis of American woodcock population and harvest trends in Canada. Pages 228-239 in D.G. Krementz, D.E. Andersen, and T.R. Cooper, Editors. Proceedings of the Eleventh American Woodcock Symposium. University of Minnesota Libraries Publishing, Minneapolis, Minnesota, USA.

Schroeder, S.A., D.C. Fulton, and J.S. Lawrence. 2006. Managing for preferred hunting experiences: a typology of Minnesota waterfowl hunters. Wildlife Society Bulletin 34:380-387.

Schulz, J.H., D.R. Luukkonen, and R.O. Morgenweck. 2010. Improving woodcock management by implementing lessons from other migratory game birds. Proceedings of the Tenth American Woodcock Symposium 10:1-11.

Seamans, M.E., and R.D. Rau. 2016. American woodcock population status, 2016. U.S. Fish and Wildlife Service, Laurel, Maryland, USA.

Sepik, G., R. Owen, and T. Dwyer. 1983. The effect of drought on a local woodcock population. Transactions of the Northeast Section of The Wildlife Society 40:1-8.

Stan Development Team. 2016. RStan: the Rinterface to Stan. Version 2.14.1. http://mc-stan.org/

Sullins, D.S., W.C. Conway, D.A. Haukos, K.A. Hobson, L.I. Wassenaar, C.E. Comer, and I.K. Hung. 2016. American woodcock migratory connectivity as indicated by hydrogen isotopes. Journal of Wildlife Management 80:510-526.

Vaske, J.J., M.P. Donnelly, T.A. Heberlein, and B. Shelby. 1982. Differences in reported satisfaction ratings by consumptive and nonconsumptive recreationists. Journal of Leisure Research 14:195-206.

Vaske, J.J., A.J. Fedler, and A.R. Graefe. 1986. Multiple determinants of satisfaction from a specific waterfowl hunting trip. Leisure Sciences 8:149-166.

Vrtiska, M.P., J.H. Gammonley, L.W. Naylor, and A.H. Raedeke. 2013. Economic and conservation ramifications from the decline of waterfowl hunters. Wildlife Society Bulletin 37:380-388.

Wynveen, C.J., D.A. Cavin, B.A. Wright, and W.E. Hammitt. 2005. Determinants of a quality wild turkey hunting season. Environmental Management 36:117-124.

Zimmerman, G.S., W.A. Link, M.J. Conroy, J.R. Sauer, K.D. Richkus, and G.S. Boomer. 2010. Estimating migratory game-bird productivity by integrating age ratio and banding data. Wildlife Research 37:612-622.

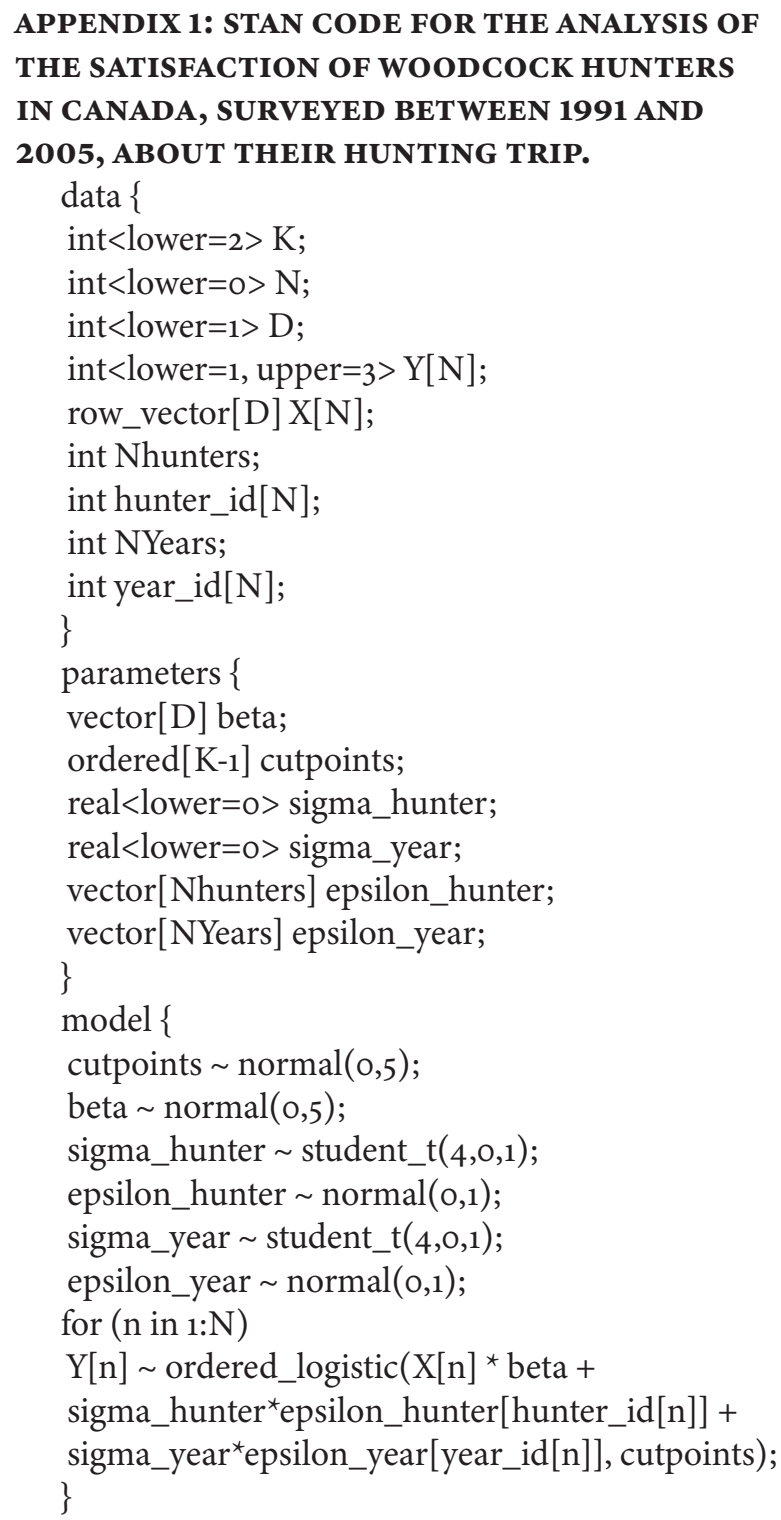

